\title{
INSECTICIDE-TREATED BED NETS IN RONDÔNIA, BRAZIL: EVALUATION OF THEIR IMPACT ON MALARIA CONTROL
}

Gabriel de Deus VIEIRA(1), Sergio de Almeida BASANO(1), Tony Hiroshi KATSURAGAWA(1,2) \& Luís Marcelo Aranha CAMARGO(1,3)

\begin{abstract}
SUMMARY
Mosquito nets treated with long-lasting insecticide (LLINs), when used in compliance with guidelines of the World Health Organization, may be effective for malaria vector control. In 2012, approximately 150,000 LLINs were installed in nine municipalities in the state of Rondônia. However, no studies have assessed their impact on the reduction of malaria incidence. This study analyzed secondary data of malaria incidence, in order to assess the impact of LLINs on the annual parasite incidence (API). The results showed no statistically significant differences in API one year after LLIN installation when compared to municipalities without LLINs. The adoption of measures for malaria vector control should be associated with epidemiological studies and evaluations of their use and efficiency, with the aim of offering convincing advantages that justify their implementation and limit malaria infection in the Amazon Region.
\end{abstract}

KEYWORDS: Insecticide-Treated Bed Nets; Amazon; Rondônia; API.

\section{INTRODUCTION}

In the 1980s, the number of reported malaria cases increased in Brazil, particularly in the nine states of the Legal Amazon region, including Rondônia. By 1990, this state accounted for approximately $50 \%$ of cases $^{5}$, likely as a result of increased road openings, agricultural settlements, deforestation, and mining ${ }^{4}$, which attracted thousands of immigrants and increased the population by around $300 \%$ in the following two decades ${ }^{15}$. In 2005, despite the efforts of the Ministry of Health, 606,077 cases of malaria were reported in the Amazon Region, 118,633 (19.6\%) of which occurred in Rondônia ${ }^{5}$. This suggests that the state still contributes significantly towards disease incidence. Between 2005 and 2007, approximately $30 \%$ of the 52 municipalities of Rondônia showed a high risk of malaria transmission, with high levels of annual parasitic incidence (API) of more than 50 cases per 1,000 inhabitants; furthermore, the highest rates were concentrated in the northern and western parts of the state 5,27 . A new wave of immigrants moved to the region at the beginning of 2008, due to the construction of two hydroelectric power plants in municipalities of the state's capital city of Porto Velho. A new epidemic cycle of malaria was expected in this endemic region ${ }^{16}$, due to its epidemiology, presence of individuals with asymptomatic infections $s^{1,6}$, and the combination of large water collections and malaria vectors ${ }^{14,21,22}$.

In Brazil, the major malaria parasite vector is Anopheles darlingi ${ }^{9}$; it is also the most prevalent vector in Rondônia ${ }^{7,8,17}$. This species possesses an activity intra- and peri-domestic, although prevalent at dusk and dawn, has demonstrated activity in almost all hours of the day; it is also able to sustain disease transmission at low parasite densities ${ }^{10,20}$. Transmission is possible from asymptomatic carriers, which are also considered parasite reservoirs, making it very difficult to meet the success of this control measure ${ }^{2,7}$.

In spite of a continuous decrease in reported malaria cases since 2005, the State Agency of Health Surveillance of Rondônia (Agevisa) implemented, in 2012, the distribution of mosquito nets treated with long-lasting insecticide (LLINs) with deltamethrin by the immersion method in the proportion of $55 \mathrm{mg} / \mathrm{m}^{2}$, in several state municipalities with higher annual parasitic incidences (API). Therefore, the aim of this study was to assess the impact of LLINs on the API between 2011 and 2013 by analyzing secondary database information to evaluate API differences between municipalities with and without LLINs.

\section{MATERIALS AND METHODS}

Agevisa (2012) indicated that the installation of 159,140 LLINs was prioritized in nine municipalities of Rondônia with a high API: Alto Paraíso, Buritis, Campo Novo de Rondônia, Candeias do Jamari, Cujubim, Guajará-Mirim, Itapuã do Oeste, Machadinho do Oeste, and Nova Mamoré (Fig. 1). To assess the variation of the API in 2012, nine additional municipalities with a high API, but without installation of LLNIs (Ariquemes, Costa Marques, Montenegro, Pimenteiras do Oeste, Porto Velho, Rio Crespo, Vale do Anari, Alvorada do Oeste, and 


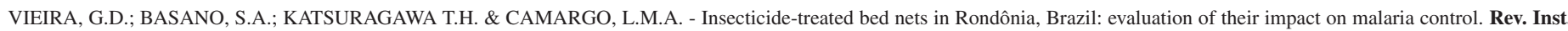
Med. Trop. Sao Paulo, 56(6): 493-7, 2014.

Cacaulândia) were also evaluated. Based on the distribution of mosquito nets, two groups were created: with and without LLINs (labeled 1-9 and A-I, respectively). The secondary database containing API information

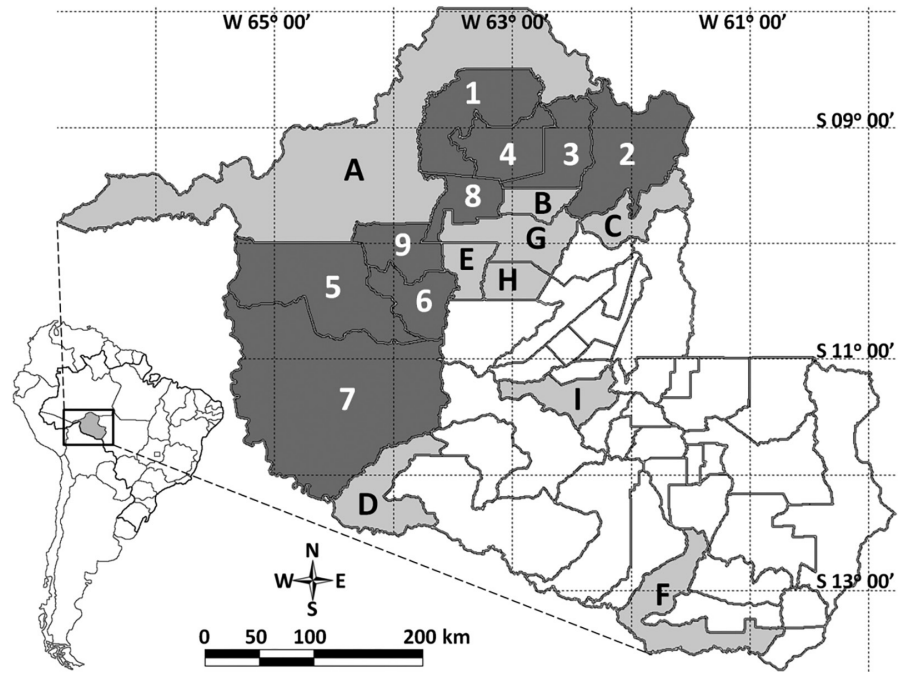

Fig. 1 - Map of the state of Rondônia with the municipalities with LLIN in dark gray (1 to 9) and without LLIN in light gray (A to I). See Table 1. was obtained through the Epidemiological Surveillance Information System (Sivep-Malária) of the Ministry of Health ${ }^{5}$.

Microsoft Excel® 2010, BioEstat 5.3, and GraphPad Prism version 5.00 were used to perform the following statistical analyses: Student's t-test for parametric comparison within the same group and MannWhitney and Kruskal-Wallis tests for non-parametric comparisons between the two groups, with a significance level of $p<0.05$. API variation was measured as the percentage ratio of API related to the previous year. The municipalities of each group were classified in descending order by the reported 2012 API values and correlated for comparative analyses as follows: one with A, two with $\mathrm{B}$, and so on (Table 1). GPS TrackMaker® Pro software, version 4.8 was used to create a location map of the study area.

\section{RESULTS AND DISCUSSION}

Comparison of API for the years before and after 2012 showed that almost all municipalities in the two groups had reduced API (Table 1). The only exception, with an increased API in 2013, was Vale do Anari, which did not use LLINs. This resulted in a positive percentage variation of API above $50 \%$. However, this outlier did not change the statistical outcome between the two groups for each year, as no significant differences were observed $(p>0.05)$. Statistical analysis of API variation between 2011

Table 1

Annual Parasite Incidence for the years 2011 to 2013 of the municipalities with and without long-lasting insecticidal nets installed, indexed in decreasing order in respect to 2012 API

\begin{tabular}{|c|c|c|c|c|c|c|c|}
\hline \multirow{2}{*}{ Municipality } & \multirow{2}{*}{ ID } & \multicolumn{3}{|c|}{ API } & \multicolumn{3}{|c|}{ API variation $(\%)$} \\
\hline & & 2011 & 2012 & 2013 & 2011 & 2012 & 2013 \\
\hline \multicolumn{8}{|l|}{ With LLIN } \\
\hline Candeias do Jamari & 1 & 269.8 & 143.7 & 82.1 & 27.7 & -46.7 & -42.8 \\
\hline Machadinho do Oeste & 2 & 86.6 & 42.9 & 23.0 & -10.9 & -50.4 & -46.4 \\
\hline Cujubim & 3 & 104.5 & 32.5 & 30.0 & -14.7 & -68.9 & -7.8 \\
\hline Itapuã do Oeste & 4 & 51.0 & 32.4 & 16.9 & -41.3 & -36.5 & -47.9 \\
\hline Nova Mamoré & 5 & 38.8 & 19.0 & 8.3 & -15.4 & -51.0 & -56.1 \\
\hline Campo Novo de Rondônia & 6 & 36.8 & 18.7 & 6.2 & 9.4 & -49.1 & -66.8 \\
\hline Guajará-Mirim & 7 & 20.7 & 13.6 & 6.7 & -48.8 & -34.1 & -51.2 \\
\hline Alto Paraíso & 8 & 35.0 & 7.6 & 2.4 & -47.3 & -78.2 & -68.2 \\
\hline Buritis & 9 & 12.8 & 5.5 & 4.7 & -17.2 & -57.2 & -13.5 \\
\hline \multicolumn{8}{|l|}{ Without LLIN } \\
\hline Porto Velho & A & 43.6 & 35.3 & 19.6 & -20.3 & -19.0 & -44.4 \\
\hline Rio Crespo & $\mathrm{B}$ & 63.6 & 25.7 & 21.9 & -67.8 & -59.6 & -14.7 \\
\hline Vale do Anari & $\mathrm{C}$ & 20.2 & 17.7 & 27.2 & -40.6 & -12.8 & 54.0 \\
\hline Costa Marques & $\mathrm{D}$ & 14.4 & 14.0 & 7.5 & -49.5 & -2.9 & -46.7 \\
\hline Monte Negro & $\mathrm{E}$ & 11.1 & 7.5 & 5.4 & -7.6 & -33.0 & -27.9 \\
\hline Pimenteiras do Oeste & $\mathrm{F}$ & 25.1 & 7.0 & 4.4 & -10.8 & -72.2 & -37.1 \\
\hline Ariquemes & G & 5.9 & 2.2 & 1.8 & -57.4 & -62.3 & -18.8 \\
\hline Cacaulândia & $\mathrm{H}$ & 5.1 & 1.9 & 0.9 & 3.6 & -62.3 & -54.8 \\
\hline Alvorada do Oeste & $\mathrm{I}$ & 2.1 & 1.9 & 1.0 & -22.2 & -10.2 & -47.7 \\
\hline Mann Whitney test ( $p$-value) & & 0.0244 & 0.0770 & 0.2224 & 0.3865 & 0.3401 & 0.1903 \\
\hline
\end{tabular}

ID: identification; API: annual parasite incidence; LLIN: long-lasting insecticidal nets. 
and 2012 also showed no statistically significant differences between groups, suggesting similar API reduction in both groups. The API difference between the two groups was statistically significant only in $2011(p=0.0244)$.

When the API was assessed between 2011 and 2013 (Table 2), it was observed that only the group using LLINs showed a statistically significant difference (Kruskal-Wallis: $p=0.0181$ ), which was higher before the installation of LLINs, 2011-2012 ( $p=0.0193)$. The group without LLINs showed no statistically significant differences in API

Table 2

Comparative analysis of the API and API variation in the analyzed years, for both groups with and without LLIN

\begin{tabular}{lcc}
\hline Variable analysis & $\begin{array}{c}\text { With LLIN } \\
(p \text {-value })\end{array}$ & $\begin{array}{c}\text { Without LLIN } \\
(p \text {-value })\end{array}$ \\
\hline API & & \\
\hline
\end{tabular}

Paired t test

2011-2012

0.0193

0.0670

2012-2013

0.0404

0.2672

Tukey's multiple comparison test.

Significant? $p<0.05$ ?

$$
\begin{aligned}
& \text { 2011-2012 } \\
& 2011-2013 \\
& 2012-2013
\end{aligned}
$$

Dunn's multiple comparison test.

Significant? $p<0.05$ ?

$$
\begin{aligned}
& \text { 2011-2012 } \\
& \text { 2011-2013 } \\
& \text { 2012-2013 }
\end{aligned}
$$

Kruskal-Wallis test

Kruskal-Wallis test (with versus without LLIN)

\section{API variation (\%)}

Paired t test
2011-2012
0.0066
0.6025
2012-2013
0.4090
0.4429

Tukey's multiple comparison test.

Significant? $p<0.05$ ?

$\begin{array}{lcc}2011-2012 & \mathrm{Y} & \mathrm{N} \\ 2011-2013 & \mathrm{Y} & \mathrm{N} \\ 2012-2013 & \mathrm{~N} & \mathrm{~N}\end{array}$

Dunn's multiple comparison test.

Significant? $p<0.05$ ?

\begin{tabular}{lcc}
$2011-2012$ & $\mathrm{Y}$ & $\mathrm{N}$ \\
$2011-2013$ & $\mathrm{~N}$ & $\mathrm{~N}$ \\
$2012-2013$ & $\mathrm{~N}$ & $\mathrm{~N}$ \\
uskal-Wallis test & 0.0139 & 0.8251 \\
$\begin{array}{l}\text { uskal-Wallis test (with versus } \\
\text { thout LLIN) }\end{array}$ & \multicolumn{2}{c}{0.2285} \\
long-lasting insecticidal nets. API: annual parasite incidence. N: no. Y: yes.
\end{tabular}

$(p>0.05)$. Therefore, the API variation was not so different from the results of the API.

However, no statistically significant differences were observed between groups with and without LLINs for both the API and API variation (Kruskal-Wallis test: API: $p=0.0993$; API variation: $p=$ 0.2285 ). The results showed decreased API and similar API variation in both groups. Therefore, LLINs had no impact on malaria incidence in the municipalities in which they were installed. When API values and variation were plotted according to their median and interquartile ranges, a higher decrease in the API variation was observed in the group without LLINs (Fig. 2C, 2D).
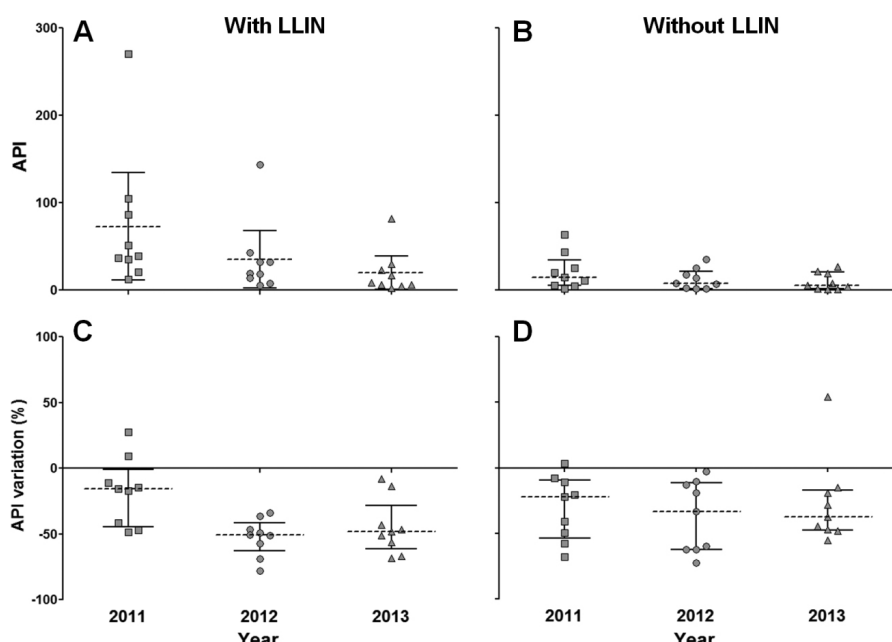

Fig. 2 - API and API variation scatter dot plot of the municipalities with and without LLIN from 2011 to 2013. Dashed line: median. Solid line: interquartile range. LLIN: long-lasting insecticidal nets. API: annual parasite incidence.

The 2012 installation of LLINs in Rondônia was not accompanied by studies to evaluate their use, effectiveness, and durability, an impediment to in-depth epidemiological and statistical analyses. However, because this control measure had already been implemented, the authors sought to evaluate its effectiveness using available information.

The major mosquito vector found in the Brazilian Amazon feeds predominantly in the early evening, when individuals are outside their homes and not protected by LLINs ${ }^{25}$. Feeding habits may be a contributing factor to the low API reduction observed in this study. The absence of studies to assess the impact of LLINs on the reduction of vector density and number of bites do not support their large-scale use in this region ${ }^{18}$.

When evaluated as a malaria control measure, LLIN use was associated with reduced bites and consequent decreases in parasitemia and anemia in resident populations ${ }^{3,26}$. However, most studies on the efficiency of LLINs are carried out in Africa, where the predominant vectors are other anopheline species with different behaviors ${ }^{13}$ from Brazilian species ${ }^{11,12,17,19}$. Moreover, the only study on this subject was carried out in Brazil at the end of the 1990s, and it describes the poor adherence of the population to use mosquito nets ${ }^{23,24}$, a measure that also did not reduce the incidence of malaria. According to SANTOS (1999) ${ }^{24}$ among the reasons for the low use of mosquito nets, are the trips, overnights spent in the fields, high temperatures, nights getting out of 
VIEIRA, G.D.; BASANO, S.A.; KATSURAGAWA T.H. \& CAMARGO, L.M.A. - Insecticide-treated bed nets in Rondônia, Brazil: evaluation of their impact on malaria control. Rev. Inst. Med. Trop. Sao Paulo, 56(6): 493-7, 2014.

bed to urinate and constant handling of the mosquito nets, reducing the amount of insecticide impregnated. Another reason for low adherence of the population, is that people can be bitten by mosquitoes on entering and leaving the mosquito net, and if there are holes in the mosquito net, this enables the entry of Anopheles.

The statistical analysis of the API and its annual percentage variation revealed that the use of LLINs in Rondônia municipalities did not significantly reduce the API. The absence of parallel scientific studies to evaluate LLIN use, handling, and impact of associated epidemiological parameters on the incidence of malaria precludes more accurate analyses on their effectiveness and cost-benefit analyses of the control measure of this disease.

Given the significant national reduction of reported malaria cases, especially in the Brazilian Amazon, future control measures aim to eradicate the parasite, making it essential to design scientific evaluation studies alongside the implementation of new strategies for disease control, as these assessments will support decision-making.

\section{RESUMO}

\section{Mosquiteiros impregnados com inseticida em Rondônia, Brasil: avaliação do impacto na incidência da malária}

O uso de mosquiteiros impregnados com inseticida de longa duração (MILD), quando obedecidas as orientações da Organização Mundial da Saúde, é medida de controle de vetores da malária que pode apresentar excelentes resultados. Em 2012 foram instalados aproximadamente 150.000 MILDs em nove municípios do estado de Rondônia. Concomitantemente não houve estudo de avaliação de impacto na redução da incidência. $\mathrm{O}$ presente estudo analisou dados secundários da incidência, na expectativa de avaliar o impacto dos MILDs na incidência parasitária anual (IPA). Os resultados estatísticos mostram que, no período de um ano após a instalação dos MILDs, não houve diferença estatisticamente significativa na variação da IPA em relação a outros municípios que não receberam os MILDs. A adoção de medidas de controle vetorial deve ser acompanhada de estudos epidemiológicos e de avaliação de uso e eficácia para oferecer subsídios mais robustos que justifiquem a adoção desta medida de controle da malária na Região Amazônica.

\section{ACKNOWLEDGEMENTS}

The authors would like to thank Moreno de Souza Rodrigues for reviewing the statistical analysis.

\section{REFERENCES}

1. Alves FP, Durlacher RR, Menezes MJ, Krieger H, Silva LHP, Camargo EP. High prevalence of asymptomatic Plasmodium vivax and Plasmodium falciparum infections in native Amazonian populations. Am J Trop Med Hyg. 2002;66:641-8.

2. Alves FP, Gil LHS, Marrelli MT, Ribolla PE, Camargo EP, Pereira da Silva LH, et al. Asymptomatic carriers of Plasmodium spp. as infection source for malaria vector mosquitoes in the Brazilian Amazon. J Med Entomol. 2005;42:777-9.

3. Antonio-Nkondjio C, Demanou M, Etang J, Bouchite B. Impact of cyfluthrin (Solfac EW050) impregnated bed nets on malaria transmission in the city of Mbandjock: lessons for the nationwide distribution of long-lasting insecticidal nets (LLINs) in Cameroon. Parasit Vectors. 2013;6:10.
4. Barata RCB. Malária no Brasil: panorama epidemiológico na última década. Cad Saude Publica. 1995;11:128-36.

5. Brasil. Ministério da Saúde. Sistema de Informação de Vigilância Epidemiológica SIVEP-Malária. [cited 2014 Jan 17]. Available from: http://portalweb04.saude.gov. br/sivep_malaria/default.asp

6. Camargo LM, Ferreira MU, Krieger H, Camargo EP, Da Silva LHP. Unstable hypoendemic malaria in Rondonia (Western Amazon region, Brazil): epidemic outbreaks and work-associated incidence in an agro-industrial rural settlement. Am J Trop Med Hyg. 1994;51:16-25.

7. Camargo LMA, Noronha E, Salcedo JMV, Dutra AP, Krieger H, Pereira da Silva LH, et al. The epidemiology of malaria in Rondonia (Western Amazon region. Brazil): study of a riverine population. Acta Trop. 1999;72:1-11.

8. Cruz RMB, Gil LHS, Silva AA, Araújo MS, Katsuragawa TH. Mosquito abundance and behavior in the influence area of the hydroelectric complex on the Madeira River, Western Amazon, Brazil. Trans R Soc Trop Med Hyg. 2009;103:1174-6.

9. Deane LM, Causey CR, Deane MP. Nota sobre a distribuição e a biologia dos anofelinos das regiões nordestina e amazônica do Brasil. Rev Serv Espec Saúde Pública (Rio J). 1948;1:827-965.

10. Galardo AK, Arruda M, D'Almeida Couto AA, Wirtz R, Lounibos LP, Zimmerman RH. Malaria vector incrimination in three rural riverine villages in the Brazilian Amazon. Am J Trop Med Hyg. 2007;76:461-9.

11. Gil LHS, Alves FP, Zieler H, Salcedo JMV, Durlacher RR, Cunha RPA, et al. Seasonal malaria transmission and variation of anopheline density in two distinct endemic areas in Brazilian Amazonia. J Med Entomol. 2003;40:636-41.

12. Gil LHS, Tada MS, Katsuragawa TH, Ribolla PEM, Pereira da Silva LH. Urban and suburban malaria in Rondônia (Brazilian Western Amazon). II. Perennial transmissions with high anopheline densities are associated with human environmental changes. Mem Inst Oswaldo Cruz. 2007;102:271-6.

13. Githeko AK, Adungo NI, Karanja DM, Hawley WA, Vulule JM, Seroney IK, et al. Some observations on the biting behavior of Anopheles gambiae s.s., Anopheles arabiensis, and Anopheles funestus and their implications for malaria control. Exp Parasitol. 1996;82:306-15.

14. Gomes AC, Paula MB, Duarte AM, Lima MA, Malafronte RS, Mucci LF, et al. Epidemiological and ecological aspects related to malaria in the area of influence of the lake at Porto Primavera dam, in western São Paulo State, Brazil. Rev Inst Med Trop Sao Paulo. 2008;50:287-95.

15. Katsuragawa TH, Gil LHS, Tada MS, Pereira da Silva LH. Endemias e epidemias na Amazônia: malária e doenças emergentes em áreas ribeirinhas do Rio Madeira. Um caso de escola. Estudos Av. 2008;22:111-41.

16. Katsuragawa TH, Cunha RPA, Souza DCA, Gil LHS, Cruz RBM, Silva AAE, et al. Malária e aspectos hematológicos em moradores da área de influência dos futuros reservatórios das hidrelétricas de Santo Antônio e Jirau, Rondônia, Brasil. Cad Saúde Pública. 2009;25:1486-92.

17. Klein TA, Lima JBP. Seasonal distribution and biting patterns of Anopheles mosquitoes in Costa Marques, Rondonia, Brazil. J Am Mosq Control Assoc. 1990;6:700-7.

18. Martins-Campos KM, Pinheiro WD, Vítor-Silva S, Siqueira AM, Melo GC, Rodrigues IC, et al. Integrated vector management targeting Anopheles darlingi populations decreases malaria incidence in an unstable transmission area, in the rural Brazilian Amazon. Malar J. 2012;11:351.

19. Morais SA, Urbinatti PR, Sallum MA, Kuniy AA, Moresco GG, Fernandes A, et al. Brazilian mosquito (Diptera: Culicidae) fauna: I. Anopheles species from Porto Velho, Rondônia State, western Amazon, Brazil. Rev Inst Med Trop Sao Paulo. 2012;54:331-5. 
20. Oliveira-Ferreira J, Lourenço-de-Oliveira R, Teva A, Deane LM, Daniel-Ribeiro CT. Natural malaria infections in anophelines in Rondonia State, Brazilian Amazon. Am J Trop Med Hyg. 1990;43:6-10.

21. Parise EV, Araujo GC, Castro JGD, Berdarrain FP. Epidemiological profile of malaria in the state of Tocantins, Brazil, from 2003 to 2008. Rev Inst Med Trop Sao Paulo. 2011;53:141-7.

22. Sanchez-Ribas J, Parra-Henao G, Guimaraes AE. Impact of dams and irrigation schemes in anopheline (Diptera: Culicidae) bionomics and malaria epidemiology. Rev Inst Med Trop Sao Paulo. 2012;54:179-91.

23. Santos JB, Santos F, Marsden P, Tosta CE, Andrade ALSS, Macêdo V. Ação dos mosquiteiros impregnados com deltametrina sobre a morbidade da malária em uma área da Amazônia Brasileira. Rev Soc Bras Med Trop. 1998;31:1-9.

24. Santos JB. Baixa aderência e alto custo como fatores de insucesso do uso de mosquiteiros impregnados com inseticida no controle da malária na Amazônia Brasileira. Rev Soc Bras Med Trop. 1999;32:333-41.
25. Silva-Nunes M, Moreno M, Conn JE, Gamboa D, Abeles S, Vinetz JM, et al. Amazonian malaria: asymptomatic human reservoirs, diagnostic challenges, environmentallydriven changes in mosquito vector populations, and the mandate for sustainable control strategies. Acta Trop. 2012;121:281-91.

26. Skarbinski J, Mwandama D, Luka M, Jafali J, Wolkon A, Townes D, et al. Impact of health facility-based insecticide treated bednet distribution in Malawi: progress and challenges towards achieving universal coverage. PLoS One. 2011;6:e21995.

27. Vieira GD, Gim KNM, Zaqueo GM, Alves TC, Katsuragawa T, Basano SA, et al Reduction of incidence and relapse or recrudescence cases of malaria in the western region of the Brazilian Amazon. J Infect Dev Ctries. 2014;8:1181-7.

Received: 3 February 2014

Accepted: 24 March 2014 